\title{
Looking for a Life: Nigerian Students Discuss Their Decisions to Study in China
}

\author{
Howard Lorne Martyn ${ }^{1}$ \\ ${ }^{1}$ School of English for International Business, Guangdong University of Foreign Studies, China \\ Correspondence: Howard Lorne Martyn. E-mail: howardeap@gmail.com
}

Received: April 24, 2019

Accepted: May 1, 2019

Online Published: May 31, 2019

doi:10.5539/ass.v15n6p30

URL: https://doi.org/10.5539/ass.v15n6p30

\begin{abstract}
The decision to migrate for (ostensibly) educational purposes, is often accompanied by psycho-social feelings of fear, sadness, guilt, pride, happiness and courage. In this report, which is part of a larger study concerning Nigerian student migration to China, five Nigerian university students discuss their motivations for leaving home and studying in China. Students were interviewed on several occasions either on the campus of their university in Guangdong province, China, or in another convenient location near the campus. Narratives were transcribed and examined for commonalities in terms of reasons given for leaving Nigeria, and affective psycho-social feelings surrounding students' decisions. Narratives are presented in first person accounts and coded for categorical content and episodic form. Episodic form is then graphed, not for quantitative analysis, but to show the positive, neutral and negative affective emotion, displayed during discussions on specific topics. Results reveal a high degree of pride in personal ability, and in the industriousness of kin. They also reveal happiness and a sense of satisfaction by participants in moving their lives forward, and being able to help family members in Nigeria. However, there were also feelings of sadness, anger and frustration at Nigeria's poor economy, which participants believe is the result of government ineptitude and corruption. This study is limited in that it only considers male Nigerian migrants of the Igbo tribe, studying in Guangdong province. Future researchers are advised to widen the geographical area, include other Nigerian tribal members, and women.
\end{abstract}

Keywords: Nigerian migrants, narrative inquiry, content analysis, episodic form analysis

\section{Introduction}

Historically migration within and from Nigeria has followed three distinct patterns. The first two of these are pre-colonial, the third post-colonial. Firstly, there was, and continues to be, considerable migration both from northern agricultural areas, particularly from Borno, Sokoto and Kano states to the delta areas of Lagos, Rivers and Edo states, and particularly to the larger industrial cities of Lagos, Port-Harcourt and Benin City. This is economic migration, waxing and waning from year to year, partly dependent upon weather and harvest conditions, but also dependent upon industrial needs of the southern states. But the migration also flows in the other direction, from south to north. Osba (1969) points out that traditionally we think of economic migration in Nigeria going from north to south, that is, from lesser developed to more developed areas. But that, he believes, is misleading. There is a tendency to think of northern Nigeria as less developed than the south, and while this is true to some extent, pockets of developed areas in the north - particularly within the cities of Kano, Kaduna and Zaria, have drawn considerable numbers of migrants from the south. Intra-regional migration tends to be temporary and short term.

Secondly, regional agricultural migration occurs across national borders, between Benin, Togo and Ghana among contiguous tribes of Fulani and Hausa, within ancestral lands established long before colonial powers divided countries. Such migrations tend to be kin or tribally related trade or flows according to agricultural need drought, flood, and patterns of excesses and shortages of labor. Substantial migration flows occurred between the south-eastern areas - the Igbo homelands, to Gabon, for purposes of harvesting timber, from the mid to late $20^{\text {th }}$ century, but more recently to service the petroleum industry. With a population only one tenth that of Nigeria, a Human Development Index (HDI) country ranking of 110 (high), and a 'working poor' percentage 10 times lower than that of Nigeria (UNDP, 2018), Gabon has offered respite from unabating urban and rural poverty. This is, to an extent, kin inspired as there is a significant Igbo community in Gabon.

Thirdly, and beginning more recently, international migration has been continually rising, particularly from 
south-eastern Igbo areas of Nigeria to developed countries, as people search for work and study opportunities. Preferred destinations in order of commonality are the US, UK, Canada, Malaysia, UAE, and Europe (Akanle, 2012). However, there has been a significant shift in recent years due to more restrictive immigration regimes which coincide with discourses that discuss South-North migration in terms of perceived security threats (Obi, 2010). Since the founding of the People's Republic, China has positioned itself as a friend to developing countries, both in terms of trade, and education, and this has taken a dramatic upswing under the current Xi Jinping government. Migration from Nigeria, and other Second and Third World countries has increased dramatically; most of this is for trade, and, ostensibly, educational purposes. Although there are comprehensive statistics concerning migration, as discussed below, there is a dearth of information concerning the pre-departure psycho-social influences propelling Nigerians to leave their homeland to sojourn in China. In this paper, which is based upon semi-structured interviews, lengthy narratives, and observational data collected from Nigerian university students studying in Guangdong, China, I discuss the given rationale and the evident psycho-social manifestations associated with studying abroad.

\section{Study Abroad Migration}

Cultural and historical forces leading to the dislocation and uprootedness of entire populations in late modernity have, to an extent, lead to a crisis in psycho-social identity. Hammack (2008) believes that identity is formed by cognitive, social and cultural phenomenon that together "are manifest in a personal narrative constructed and reconstructed across the life course, and scripted in and through social interaction and social practice"(p.223). Such narratives often reveal "contested collective meaning [whereby] individuals may be motivated to adopt an identity that preserves a sense of ontological security that minimizes existential anxiety" (pp. 222-225). The strength of that motivation is influenced by psycho-social necessity, often accompanied by a personal need to find fulfillment through education or work. In the case of individuals struggling through personal or social disruption, a change of physical surroundings from areas of social upheaval to areas of relative tranquility, accompanied by hopes of future financial wellbeing, may enable not only the minimization of anxiety, but bring renewed hope for a meaningful and rewarding future: enrolling in study abroad programs is the initial route many select.

Study migration has traditionally flowed from less-developed to more highly developed countries; from the educational periphery to the educational center (Altbach, 2007). Organization for Economic Co-operation and Development numbers indicate an overall increase from about 3 million in 2005, to about 4.5 million in 2015, with $73 \%$ (2015) studying in OECD countries, primarily the European Union, the United States, the United Kingdom and France. Students from Asia accounted for $53 \%$ of study abroad students, and of those, $22 \%$ hailed from China, the largest share among reporting countries. But China is unique in that, to an extent, it is balancing this trend as its acceptance of foreign students has also been rising dramatically, from approximately 250,000 in 2009 to 442,000 in 2016, over $2 \%$ of the worlds tertiary international student population (OECD, 2016). China has become both the largest supplier of foreign students in the world, and the 2nd largest destination for foreign university students, after Japan, in Asia. Indeed, China's Ministry of Education (MOE), in 2015, proposed raising the then number of international students in the country from 398,000 to 500,000 by 2020 (Wen \& Hu, 2018). According to the MOE (2018), it has largely succeeded in that goal, with 489,000 as of 2017. In 2018 the MOE reported that 81,562 students or $16.57 \%$ of international students hailed from Africa (2019), a substantial increase over the 49,792 or 12.52 percent from Africa in 2015 (2016). A breakdown of student numbers from specific African countries was not available.

Many of these students hail from areas of disadvantage relative to China, a situation likely to continue. China's educational systems are likely to come under increasing strain due to psycho-social, cross-cultural tensions, along with changing financial life goals of foreign students. A crucial goal in mitigating potential conflict is to understand the familial, work, and psycho-social backgrounds of migrant students; the current narrative study aims to contribute toward that goal.

China has been increasing its placements and scholarships for Nigerian students. In 2010 it initiated its "Study in China Program", encouraging Nigerian, and other international students, to consider China as an educational destination. That program was further propelled by the country's drive in educational development through the aggressive "Double First Class" initiatives begun in 2015 (Peters \& Besley, 2018). This has resulted in increased enrollment of foreign students, the majority from Global South countries.

\section{Narrative Inquiry}

I employ a life story, narrative inquiry regime in the collection of data. Adler, Lodi-Smith, Philipe and Houle (2016) suggest that individuals life stories ought to be understood as core elements of personality that are 
associated with psycho-social well-being; narratives provide clear predictors of contentment which includes satisfaction and success in chosen endeavors. Importantly, they stress that the creation of meaning from narratives assists in the formation of personal identity and life purpose.

Waterson (2007) believes that narrative methodology is a greatly underutilized research tool within the social sciences, due in part to the open parameters concerning how to present and analyze records of personal historical experiences; perception is fuzzy and open to wide interpretation. Nevertheless, having engaged in narrative methodology for over 40 years, she believes its strengths and weakness are one in the same, lying in the uniqueness of personal voice - usually multiplied countless times by those who have gone through similar experiences. In countries such as Nigeria where it is common for individuals, even of a relatively young age, to feel the conflicting demands of kin, tribe, state governments, national governments, and uncontrolled insurrectionist movements, lives become politicized by competing values and allegiances. Narrative inquiry, at its core, is concerned with revealing these politicized fractures and how they have impacted individuals.

Hoskins (2007) feels that, even within a homogeneous society, it is the uniqueness of perspectives, or engagement with the breadth of perspectives that provides insight, and that this breadth of perspective may be demonstrated in a variety of ways. Some of these include genre, the politics of public and personal memory, and views / remembrances that oppose those considered historically accurate.

Genre may include songs, poems, storytelling, acting or reference to objects held or discussed by participants. Heirlooms, weapons - especially if used in combat, and articles of personal religious significance are sometimes used as a focus for discussion. Often discussion centers on the perceived life quality enhancement, or the ability to triumph over adversity that the object has afforded the participant. Hoskins (2007) advises that personal triumph against adversary - "the Hortaio Alger story genre in American culture, where a young hero strives against adversity to achieve fame and fortune" (p. 93), occasionally surfaces in personal narratives. In terms of the politics of memory, Hoskins (2007) indicates that researchers should be aware of the sometimes quickly changing features of societal power relations and the effect that these may have (or not have) on the relaying of events. This is particularly important where participants futures may be influenced by governments or cultures sensitive to adverse comments. Individual experiences and views do not necessarily represent what is often taken to be the wider historically accepted view of events. Hoskins (2007) draws our attention to the fact that one can experience success and prosperity in the midst of cultural deprivation and chaos. Such narratives serve to highlight the uniqueness of individual lives.

Polkinghorne (1988) describes the ideal narrative as a "gathering of events into a meaningful story ... through which life events are conjoined into coherent, meaningful, unified themes" (pp. 126, 131). He points out that narration should be more than simply a recording of events; or more even than a recording of events with analysis. It is the creation of personal identity, the construction of events, and perhaps most importantly, the allocation of merit or noteworthiness. Clandinin and Connelly's (2000) simply put truism provides the grounding: "Why narrative? Because experience" (p. 50). Clandinin and Connelly (1994), expanding on Dewey's belief that narratives must be contextualized within situation, continuity and interaction, feel that narratives should also reach inward to our hopes, feelings, aesthetic and moral values; in effect establishing the locus of identity control, as well as extending outwards, affecting the reader and in so doing create the possibility for social transformation. Narratives are bound to memory and are thus temporal, just as they are bound to place. While economic, political and social forces have come together at a given place and time to make migration the clear alternative for those living through turmoil, those forces always bring about disjointedness, displacement and disequilibrium. They strain relationships and tests moral fiber. Economic and social injustices often precipitate. Common memory, revealed through chronicles of time and location, often point to injustices which may lead to the embarkation into new lifepaths designed to reassert agency, relocating it within the individual, a process "likely to invoke strident forms of reawakening" (Niezen, 2004, p. 40).

The examples below illustrate themes of disruptive pasts, negotiation with family members, searching for independence through education and work, and developing possibilities for future education and employment. These themes dominated participant discussions, and were placed within past, present and future timeframes. The written narratives in the remainder of this paper are authentic. Word choice and grammatical changes have been made only when clarification is necessary.

\section{Method}

I employ a social-constructivist narrative approach to data collection. Such inductive methodologies are utilized to avoid the binary dichotomies typically found in positivist statistical research. People's storied lives become prominent: we imagine a face, rather than see a statistic. Narrative data collection is often the method of choice 
when the researcher wishes to allow the participant maximum unrestricted expression, or when the participant might wish to control the direction of the interview. For example, Riessman (2015), and Morris (2017) allow participants the narrative latitude to discuss their end of life experiences while undergoing severe illness. Bury (2001) discusses how individuals lose personal identity when undergoing traumatic illness when subsumed into the bio-medical 'grand narrative'. Gray (2001) investigates coping strategies of autistic teenagers and their parents in meeting the challenges of daily life. Murray (2010) utilizes story-telling and narrative with adolescents suffering from family stress and breakdown. Brante (2012) investigates critical incidents among teachers in abhorrent working conditions, using narrative interviews. Gonzalez-Lopez (2015) invokes narrative methodology to examine the effects of psycho-therapy used with adolescents suffering the after-effects of physical abuse. Klots (2011) uses narrative methodology in order to uncover the overt and hidden lives of migrants in the United States. Benish-Weissman (2009) uses narrative interviews as a starting point to discuss immigrant trauma among two dozen Soviet migrants in the Middle East. Martyn (2018a, 2018b) uses a narrative methodology in discussing social action planning in an educational setting among migrant workers in Asia.

Denzin (1989) describes narrative data collection as:

Tales of events that are significant for the narrator and his or her audience. A narrative as a story has a plot, a beginning, a middle and an end. It has internal logic that makes sense to the narrator. A narrative relates events to a temporal, causal sequence (p. 37).

Although narratives may progress from a beginning to an end, structurally, the story itself may follow no particular timeline. The narratives in this paper have no endings - they describe lives that are in transition; but transition does not imply limbo. In fact, the participants are moving forward, making plans, preparing for their new lives. Polkinghorne (1995) believes that narratives reveal those who are "attempting to progress to a solution, clarification, or the unravelling of an incomplete situation" (p.7). Nigerians interviewed in this study certainly fall within that description.

Student assistants, designated by departments, were contacted with requests to suggest a list of students that I could use as contact references. I specifically asked for a listings of Nigerian students and the assistants supplied me with 'Wechat' contacts. Individual students were contacted and arrangements were made to interview them individually. We met either in a common space on the campus, or at a nearby café. Interviews were recorded and later transcribed with emergent themes and patterns noted. In thematic analysis emphasis lies in the events and their implications for the speaker. As such, 'messy' language is transformed to make it more readable, with care taken not to alter meaning.

Five stories voiced by Nigerian students, studying at universities in Guangdong Province China, are analyzed. This report focuses on the pre-departure events, attendant preparations concerning the decision to study abroad, and the inherent emotional turmoil involved. Aspects of the interviews involving adaptation to life in China, including successes, frustrations, and building new relationships, and how participants felt their time in China might affect their futures in terms of possible further study, work, family and relationships, will be covered in a subsequent report. Most Igbos learn English in primary school (English is the national language of Nigeria), thus language was not a barrier to communication.

Once narratives are collected, they may be classified and organized. Lieblich, Tuval-Mashiach and Zilber (1998) classify and organize narratives into two dimensions: holistic versus categorical, and content versus form. Holistic analysis examines life stories as a whole, with sections examined in light of the whole. For example, Clough (2002) examines social and learning disfunctions among youth in disadvantaged areas of England by examining general attitudes and behaviors. Goodley (2004) examines the lives of the cognitively disadvantaged, giving them a public voice with the hope of generating public dialogue into their condition; the overall narrative provides insight into specific social disadvantage. Moore (2004) examines the life of a quadriplegic, documenting his decision to commit suicide, with the aim of improving the lives of future sufferers. Categorical analysis, or traditional content analysis, subdivides text into micro sections - sentences, phrases, individual words which are examined. This is often undertaken to shed light on a phenomenon affecting a particular group of people. For example, Pavelko and Owens (2017) use sample utterances and grammatical analysis (SUGAR) to investigate age related changes in children's abilities to cognitively transcribe and understand utterances. Ladeforged (1988) looks at micro-utterances using the International Phonetic Alphabet (IPA) to determine voiced, bilabial and, nasal sounds for insights into the voiced production of English by non-native speakers.

In the present study I select portions of the transcribed narratives, that exemplify emergent themes. Life decisions and rationales within these themes are then examined. Thus, categorical content analysis is well suited to the data. 
Holistic analysis of form examines narratives in terms of their implied story construction; that is, it takes a literary approach to analysis. Gregen and Gregen $(1986,1988)$ believe that every story can be examined in terms of its plot and can be graphed in terms of progression, regression, stasis or a combination, by examining issues that include hopes for the future, setbacks, illness, wellness, relationships, birth, death and new beginnings. In their book Narrative Means to Therapeutic Ends, White and Epston (1990) take the view that narratives may be used in aid of reassessment of a participants life view, for example from victim of circumstance to hero of his or her own life story. Their view reflects that of, Becker $(1971,1973)$, who believes that self-esteem acts as an anxiety buffer, deflecting the horror of complete self-awareness, by allowing us to become our own hero. Heroic self-esteem mitigates the lethargy and lack of life-control brought about by the terror of certain death. On the other hand, categorical analysis of form examines the complexity of description and arguments - in particular the inconsistencies, inaccuracies or illogical reasoning that may be found in narratives. Linde (1993) describes categorical-form analysis focusing on stylistic or linguistic characteristics - issues such as types of metaphors used and frequency of passive versus active utterances. The present study uses a modified version of holistic form analysis - episodic form, which categorizes emotional content.

It is important to point out that there is much overlap between dimensions. Lieblich, Tuval-Mashiach and Zilber (1998) caution us not to be overly didactic in applying analysis as, "the separation of 'whole' from 'category' is, in reality, not clearer than that between 'content' and 'form"' (p. 169).

\section{Analysis}

\subsection{Udo: Pre-Departure}

$\mathrm{Udo}^{1}$ earned a degree in economics in Nigeria, worked as a printer and graphic designer, but ultimately was unable to make a sustainable living. At 28 he decided to migrate to China.

Table 1. Udo: Pre-departure Analysis

Transcribed Text
1. My name is Udo. That is what people like to call me, so I have accepted that
name. The name has stuck itself to me.
2. I was born in Onitsha and grew up in that city. But Onitsha is a small city with
few educational opportunities, so I studied at university in Lagos and then
transferred my credits to University of Abuja where I finished my degree in
economics. I spent 8 years in Lagos and 8 years in Abuja. You know I was
working very hard to get that degree.

3. But I tell you, all the while I was studying, I was working as a designer - a graphic designer, and a printer. That will definitely be useful in my future. I need to run my own business and expand.

4. Real success means leaving Nigeria. This is a sad but true case. Actually there is a saying: 'there is no place like home'. Even if you are coming from a poor place, your home is still your home. I learn this much about my home. Africa is beautiful. If not for the bad economy no one would dream of travelling out of the country. We've got the resources. We are blessed. The leaders are mismanaging the resources.

5. I miss a lot. I miss my family. I miss what I do - I told you I was a printer. I miss the food. I miss my friends. In Nigeria I do not have to worry about what people will think of me.

6. But maybe it is a good thing. I am forced to leave and so expand and see other countries. We have a saying in Nigeria: 'So long as you are 18 you are a man". I am now 30. My relatives know I have reached a dead end, so they support me to leave Nigeria anyway I can, to make a good life. I have to look after myself. In future I will have a wife and kids, but how can I do that unless I am successful? This is a worry, because my family expects me to be a kind of big shot when I return.

7. Why China? In Nigeria there are billboards and agents promoting study in China. They offer this as a way to a future life. I have a friend who was studying in Ningbo City and he helped me to apply. He recommended an agent in Nigeria who helps with visa applications. There are Chinese consulates in Lagos and Abuja, but the agent handled the details.

\begin{tabular}{ll} 
Specific Content & \\
\hline Categorical Content & Episodic Form \\
\hline${ }^{1}$ Udo & ${ }^{1}$ pride in name \\
${ }^{2}$ finished degree & ${ }^{2,7}$ pride in ability
\end{tabular}

${ }^{3}$ run own business, expand ${ }^{3,6}$ happiness
about future
vision

${ }^{4}$ real success means leaving Nigeria ${ }^{4}$ leaders mismanaging resources

${ }^{5}$ I miss a lot

${ }^{6}$ I have reached a dead end. I am expected to be a big shot

${ }^{7}$ Agents promoting ${ }^{4}$ saddness ${ }^{4}$ pride in place study in China

\section{${ }^{5,6}$ saddness}

${ }^{6}$ proud of family support ${ }^{6}$ worry about not meeting expectations

\footnotetext{
${ }^{1}$ Participants names are pseudonyms
} 
8. Actually, I didn't have any contact with Chinese people before I came, but my brother imports goods from China and he knows people from China, though he has never been. China has a fast-growing economy and my brother is doing well, so I must also get in on this. I was advised to go to China and study on a student visa. This is the way in.

Udo discussed growing up in Onitsha and his studies in Lagos and Abuja, where he earned a degree in economics. He expressed a great deal of pride in having the tenacity to spend 16 years on and off trying to support himself while studying part time. But he considers this an important and positive period in his life as it gave him the courage to withstand the bouts of sadness encountered in China when missing his family and culture. His parents supported his move on pragmatic grounds. He is determined to overcome the cultural hurdles he has encountered and find success in an import-export business.

The decision to migrate, while often pragmatically based on the family's financial situation, is also contextualized within psychological, political, societal and emotional frames. The pre-departure migrant is put under considerable pressure to become successful and to pass on the proceeds of that success to family members. Akanle (2012) found that expectations of support, during and especially after return, were often unrealistic. The assumption is that when one is living in a relatively rich country, one's personal wealth increases proportionately. Over time this assumption will diminish, but the migrant nevertheless may feel that he has not lived up to expectations. Possibly the most primary expectation is for the migrant to return, be held in admiration because of their intrepidity and financial wherewithal, marry someone of the same kin group, produce children and become, ideally, a village elder, or notable community member. Akanle (2012) points out that people boast and flaunt having kin abroad - it raises their status, but it is also worrisome for the migrant concerned with living up to familial expectations.

McAdams et al. (1997) refers to stories that move progressively toward more situationally and emotionally negative conditions as 'contamination' sequences, while those that take a more positive upward note are referred to as 'redemption' sequences. Such sequences are typically graphed to provide a visual reference. Lieblich et al. (1998) also visually represent sequences that cause an upward, downward or irregular pattern to stories. In my analysis I graph the episodic form, the highs and lows of emotional content present in the telling of the story. Graphing is undertaken, not to quantify analysis, but to show, in general terms, the highs and lows of emotion that the participant is exhibiting through voice and gesture.

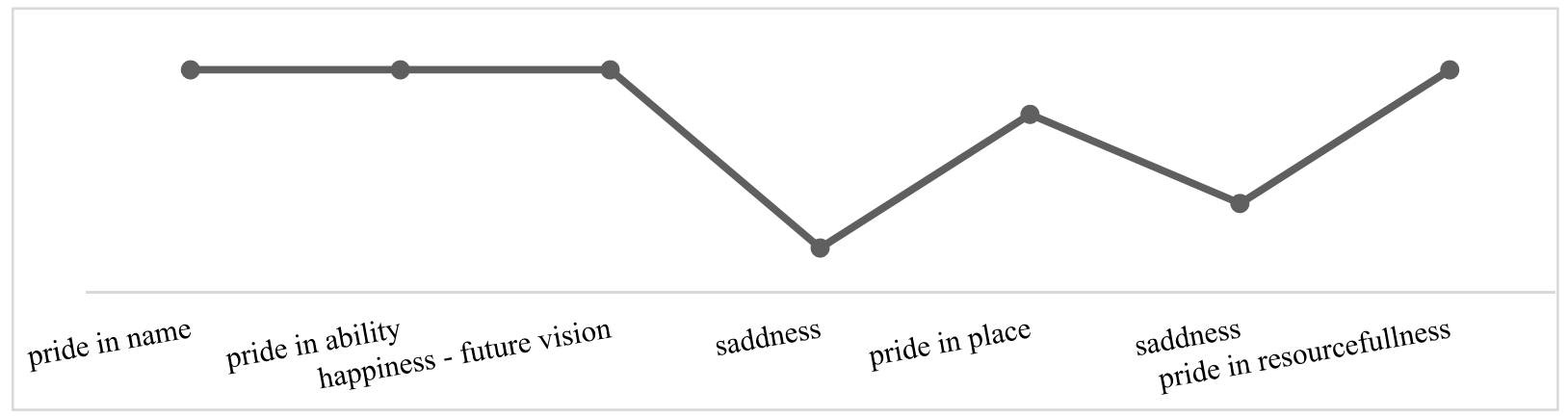

Figure 1. Udo: Episodic Form

\subsection{Okorie: Pre-Departure}

Okorie discussed his attempts at finding partners for his textile business, and the unexpected dangers lurking when civil strife disrupts a potential partnership.

Table 2. Okorie: Pre-Departure Analysis

\begin{tabular}{|c|c|c|}
\hline Transcribed Text & \multicolumn{2}{|c|}{ Specific Content } \\
\hline \multirow{3}{*}{$\begin{array}{l}\text { 1. I am from Ebonyi State and I'm } 26 \text { years old. Rice farming is the main source } \\
\text { of income in Ebonyi. But we also have limestone. We are rich in natural } \\
\text { resources. I already have a business. I'm into cottons and textiles. I also have a } \\
\text { registered company in Ebonyi. }\end{array}$} & Categorical Content & Episodic Form \\
\hline & ${ }^{1}$ I already have a & ${ }^{1}$ pride in skills \\
\hline & $\begin{array}{l}\text { business - cottons } \\
\text { and textiles }\end{array}$ & ${ }^{2,3}$ happiness at \\
\hline
\end{tabular}


2. My company imports textiles. We are now a minor concern in Ebonyi, but I am ${ }^{2}$ potential growth future thinking to partner up with another company in the future. That will give a lot of growth potential. But I must be careful. The wrong partner could be a disaster, I can tell you.

3. A few years ago I travel to Maiduguri in Borno State, far to the north-east of my home, to partner with a Hausa man. I myself am Igbo, but that is not a problem for either of us. He is good man trying to run his small textile business. We are thinking to sell textiles in cities north to south in Nigeria by pooling our business contacts and resources. Everything is looking bright for ${ }^{4}$ having a disaster our future.

${ }^{3}$ everything is looking bright

4. We are then having a disaster. Early one morning there is gun-fire and the smell of burning. Black smoke everywhere. We are sleeping there in the back of the factory, and smoke is coming through the window. They are burning the businesses. This is Boko Haram. Being from the south I am very scared for my life. I say 'goodbye' to my partner and run and hide and escape. I spend a few days outside of Maiduguri just being quiet and sleeping anywhere. Then make my way back to Ebonyi. Some weeks later I receive letter from my partner. He is ok, but his small factory is destroyed, so now he has nothing.

5. You see what these Boko Haram people are like. In another country they would be crushed. But here in Nigeria the military does nothing. As long as the corrupt president and politicians are safe, they don't care about the common people.

6. I never met a Chinese person before coming here. But I was just thinking that this is the way forward because China is a forward looking country, with good business opportunity, especially in textiles.

7. My parents were very happy when I said I was going to China. They say I

${ }^{5}$ the military does nothing

${ }^{6}$ the way forward

${ }^{7}$ my parents were very

happy

${ }^{8}$ second visa much

easier

great progress in

Chinese
${ }^{4}$ fear, anger

${ }^{5}$ frustration

${ }^{6,9}$ hope for the future

${ }^{7}$ delight in approval

${ }^{8}$ happy with visa

${ }^{9}$ happy at

Chinese

progress should export textiles from China and they will handle the business at the Ebonyi end.

8. But it was not easy for me to get a visa. The first visa was for 8 months, then I had to return home. But the second visa was much easier.

9. Another thing is I am making great progress in Chinese. It is so much easier to do business here if you are fluent in Chinese and I am working very hard toward that.

Okorie is very ambitions - not about to be kept down by one or two regretful decisions or a slow economy. His attitude is one of fibrousness, a toughness that will protect him from failure. During most of our conversation he was upbeat, convinced he could take on difficult situations and rise above the chaos. His biggest frustration was, surprisingly, not the encounter with Boko Haram, but with the ineffective military response to that threat. The upbeat attitude was contaminated at the mention of Boko Haram and the military, but Okorie quickly recovered to describe his parents delight in his decision to migrate to China, knowing that his best hope for the future lie outside of Nigeria.

pride in skills happiness at future fear, anger frustration hope for the future delight in approval happy with visa chinese progress

Figure 2. Okorie: Episodic Form

Maiangwa, Uzodike, Whetho, and Onapajo (2012) believe that failure of the Nigerian government to provide security, education, health care, infrastructure, employment opportunities, and an effective legal framework for law and order, over a period of several decades, has resulted in loss of legitimacy whereby citizens, "transfer their allegiances to more responsive authority groups or figures - religious, clan, or group leaders - while others 
will go even further by becoming terrorists" (p.43). The Fragile States Index compiled yearly by the Fund for Peace and Foreign Policy graphically depicts Nigeria as having gone from a 'warning' situation in 2005, to an 'alert' situation in 2013, thus in Maiangwa, et al.'s (2012) view, bringing it close to other countries "that have experienced total collapse" (p. 43). Boko Haram's ability to kill over 600 people in large urban centers in 2011, and double that number in 2012 using young girls and women as suicide bombers, has left the population "stunned" (Maiangwa et al., p. 42). The ineptness of government forces was highlighted on January 17, 2017 when military fighter jets killed 234 people and injured over 100, camped in Borno State, believing them to be Boko Haram fighters; in fact, they were refugees, placed in that location by another branch of the military (Human Rights Watch, 2019).

\subsection{Chidi: Pre-Departure}

Chidi discussed his good fortune at being able to go abroad, despite the poor Nigerian economy and his parents precarious financial situation.

Table 3. Chidi: Pre-Departure Analysis

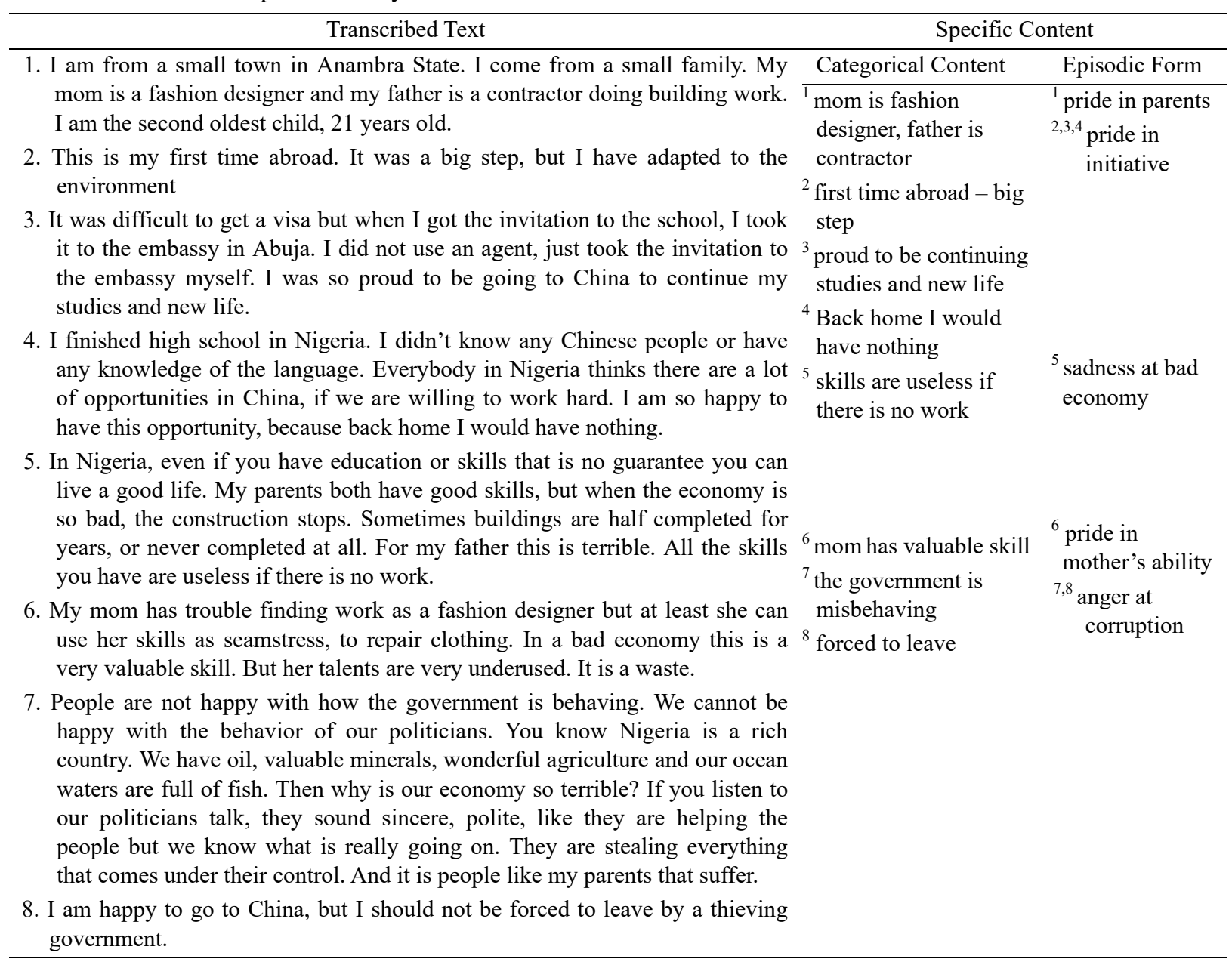

Chidi takes particular pride in his parents. This is especially so, in that his mother, a fashion designer, well known in their community, and his father, a hardware merchant and household repairman, are having financial difficulties; their limited success has been sullied by the poor economy, made worse by government corruption. Three times over the course of our interview, Chidi questioned why Nigeria was blessed with an abundance of high quality resources, yet equally cursed with corrupt politicians and administrators. This became a dominate theme in his narrative, causing him to question the purpose of his parents diligence, which could be undercut so effectively. Chidi considers himself "blessed" at being given the opportunity to study in China - and though, at 21 years old, he is not sure what direction his life will take, he believes he is on the track to success and to eventually provide financial assistance to his family.

Agbiboa (2012) discusses the link, in Nigeria, between poverty and government corruption. Seventy percent of 
the population (2011) survive on less than US \$1 per day, life expectancy is below 45 years of age, and the country sits at 159 out of 177 states on the UN human development index (2006). The government maintains predatory power and control, according to Agbiboa (2012) "through violence and bribery" (p. 325). This has its roots in kinship obligation systems, where families assist other family members, perhaps distant relatives, second cousins or tribal members, as part of their familial duty. The imposition of a government structure does not change that familial requirement, but allows corruption to "seep through the pores of a healthy body, ravaging it beyond repair" (p. 33).

pride in parents pride in initiative saddness at bad economy pride in mothers ability anger at corruption

Figure 3. Chidi: Episodic Form

\subsection{Ekene: Pre-Departure}

Ekene is very interested in learning Chinese language and culture and desires to forward his education. But he also needs to work to help support his family in Nigeria.

Table 4. Ekene: Pre-Departure Analysis

\begin{tabular}{|c|c|c|}
\hline Transcribed Text & Specific Content & \\
\hline & Categorical Content & Episodic Form \\
\hline $\begin{array}{l}\text { 1. I am } 27 \text { years old. I'm Igbo and come from the small town of Nnewi, in } \\
\text { Anambra State. The nearest big city would be Onitsha. The area around } \\
\text { my town is known for production of cars and motorcycles. Actually one } \\
\text { of the main assembly factories of vehicles is in my town. Car and truck } \\
\text { parts are shipped there from China. The factory employs quite a number } \\
\text { of people. It supports many families. }\end{array}$ & $\begin{array}{l}\text { one of the main factories } \\
\text { is in my town } \\
{ }^{2} \text { someday I may be able } \\
\text { to assist } \\
{ }^{3} \text { mom and dad worked } \\
\text { hard all their lives }\end{array}$ & $\begin{array}{l}{ }^{1} \text { pride in place } \\
{ }^{2,3} \text { desire to help } \\
\text { parents }\end{array}$ \\
\hline $\begin{array}{l}\text { 2. My parents are also from that area. My mon sells local foods and my dad, } \\
\text { he sells electronics, lights, furniture, extensions. There are very few } \\
\text { things he can buy from China, because you need a lot of money to make } \\
\text { big orders. Someday I might be able to assist with that. }\end{array}$ & & ${ }^{3}$ cautious ambition \\
\hline $\begin{array}{l}\text { 3. My mom and dad worked hard all their lives. They worked on farms, then } \\
\text { in factories. Their parents could not afford to send them to school. I want } \\
\text { to be able to help out when they get older, so I need to progress, to get a } \\
\text { good job, but I don't know, good jobs are hard to get. }\end{array}$ & & \\
\hline $\begin{array}{l}\text { 4. I have } 1 \text { brother and } 3 \text { sisters. They accepted my going to China, but one } \\
\text { of my sisters said: "Why don't you go to some other country to study?" I } \\
\text { tell her I really want to learn Chinese and about the culture. China } \\
\text { interests me. My parents were supportive of me coming here; they want } \\
\text { me to travel and see other parts of the world and learn new things. }\end{array}$ & ${ }^{5}$ I should have made an & $\begin{array}{l}{ }^{4} \text { desire to learn } \\
\text { and experience } \\
\text { new cultures }\end{array}$ \\
\hline $\begin{array}{l}\text { 5. I didn't know any Chinese people or anything about the Chinese language } \\
\text { before coming here. There are more Chinese restaurants in Anambra now } \\
\text { than in the past, but still I didn't know anyone from China. I should have } \\
\text { made an effort then, to meet some of those Chinese people, but I was }\end{array}$ & $\begin{array}{l}\text { effort to meet Chinese } \\
\text { people }\end{array}$ & $\begin{array}{l}{ }^{6} \text { pride in Chinese } \\
\text { ability }\end{array}$ \\
\hline $\begin{array}{l}\text { busy working in a factory. } \\
\text { 6. I am interested in Chinese now. I did my HSK } 4 \text { exam and am waiting for } \\
\text { the result. I want to be able to speak Chinese as well as English. }\end{array}$ & $\begin{array}{l}{ }^{7} \text { After that, I will have to } \\
\text { wait and see }\end{array}$ & $\begin{array}{l}{ }^{7} \text { conflict about } \\
\text { future }\end{array}$ \\
\hline $\begin{array}{l}\text { 7. After that? Well, I would like to do further study, but I know I need to } \\
\text { work for my family, so, I will have to wait and see. }\end{array}$ & & \\
\hline
\end{tabular}

Ekene, began by talking about his town, Nnewi, in the heart of Igboland and his pride in the industries Igbo's have created. Working in a factory provided him with a sense of family loyalty and allowed him to assist with daily expenses. Ekene's long term desire is to make business related connections that might help his father 
expand his modest electronics business, but he realizes that will only be possible if he can make significant contacts among traders in Guangzhou. Ekene did confess a strong interest in furthering his education, especially in the Chinese language, which he hopes will open new doors, both in terms of work and further education.

Bredeloup (2014) discusses the evolution of West African traders, or student-traders in Guangzhou since the 1980s, pointing out that, during the Deng Xiao Ping years there was an attempt at liberalizing trade allowing initial attempts by African students to make small inroads into the economy, though this was understandably limited until China joined the WTO in 2001. In the early 2000s African traders, along with African students, expanded into major cities, exporting small hardware and electronic items. The Sanyuanli area of Guangzhou, sometimes known as 'Little Africa' remains a thriving, though small, trading district. African students report that it is much easier to attain a student visa than a business visa, and this is the road taken by many, in their pursuit of financial success.

Ironically, although China offers opportunities for traders, including student-traders, this appears to have come at the expense of the African manufacturing industry, depressing, for example, local leather and furniture products (Ajakaiye \& Kaplinsky, 2009), generally suppressing African exports (Giovannetti \& Sanfilippo, 2016), and has resulted in only 13 out of 53 African countries, which report trade data, having a trade surplus with China (Haugen, 2012).

pride in place
desire to help parents ambition desire to learn $\quad \begin{gathered}\text { regret } \\ \text { pride in Chinese ability } \\ \text { conflict about future }\end{gathered}$

Figure 4. Ekene: Episodic Form

\subsection{Obi: Pre-Departure}

Obi, who has a degree in information management technology, hopes to improve his Chinese and find business success.

Table 5. Obi: Pre-Departure Analysis

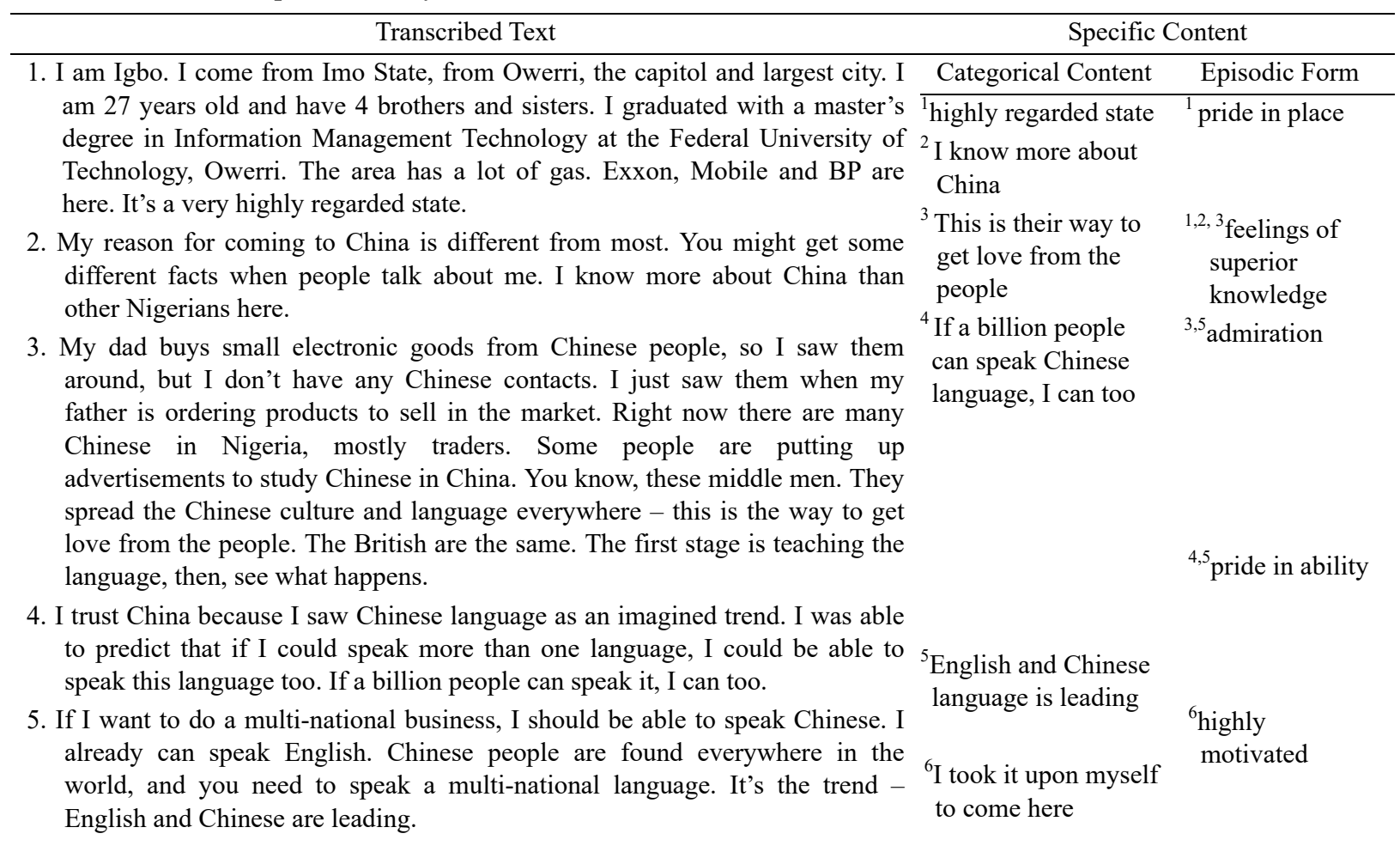


6. My parents didn't want me to forward my education, just work at some job. "Let's see after your first degree what you can do with it." That was their attitude. But I took it upon myself to come here, with my brother.

7. Usually going abroad is the work of a brother. I do this, you do this as well. You go there; you help me. You can study Chinese language; you do business with Chinese.

8. You know the saying: "We are only 3 persons away from everyone." You get to know someone, and eventually someone will help you. Nigerians have a network all over the world, so if I don't know the right person, my brother knows the right person. That person may not do much, but when you arrive, he will say: "You can stay here for the night." There is always someone like this.

$\begin{array}{lc}{ }^{7} \text { going abroad is the } & { }^{7} \text { family loyalty } \\ \text { work of a brother } & \\ { }^{8} \text { you get to know } & { }^{8} \text { trust in a } \\ \text { someone and } & \text { Nigerian } \\ \begin{array}{l}\text { eventually someone } \\ \text { will help you }\end{array} & \text { brotherhood }\end{array}$

going abroad is the

you get to know eventually someone elp you

Obi discussed the importance of friendship connections. He argued that the establishment of soft cultural promotion groups, such as language classes and cultural study groups, are a reasonable method for countries to establish bilateral relationships that aid economic prosperity. Obi believes that while it is possible for countries to effectively negotiate without these close ties, they do help to assist in establishing personal grass roots level contacts that are beyond government negotiation.

But kinship connections are primary. Obi has a network of Igbo connections in major Chinese cities, which he will eventually use for business. Obi may be an example of Bredeloup's (2014) 'second wave' of African studywork migrants in China - those that can depend upon a network established over the previous two decades, who have business contacts in place, and are willing to take on assistants from their own tribal or kinship group. Lagree (2012) discusses the opening up of university education to African students in 1999 after Jiang Zemin emphasized the importance of international students in cultural and economic exchange. A year later China established the Forum on China-Africa Cooperation (FOCAC), which established a framework by which intercultural exchanges and education could take place, paving the way for continual growth in African student numbers.

Akanle (2012) emphasizes that kinship utilization within an international context has remained a major driving force in determining where later generations of Nigerians migrate. Traditionally destinations have been the US, UK, Canada and Europe, but more recently 'chain migration' loosely based on kinship ties has been increasing in China. "Nigerians are socialized into the kinship ethos early in life . . . Nigerians primarily think of their existences within kinship systems ... even [during] international migration" (p. 139-140).

pride in place
feelings of superior knowledge pride in ability high motivation family loyalty
trust in Nigerian brotherhood

\section{Discussion}

Figure 5. Obi: Episodic Form

In this paper I have discussed the migration decisions of five Nigerian university students, who are currently studying in Guangdong Province, China. The motivations behind their decisions to study abroad are highly influenced by the economic and political situations in Nigeria. Each of these participants was of the opinion that, in order to have authority over their own lives, they needed to leave their country to seek educational and job opportunities.

China has positioned itself as a major supplier of textiles, electronics, household goods and hand tools to the Nigerian market, and has provided opportunities for Nigerian traders, and student-traders, to directly benefit. New migrants to China often take advantage of an informal network of traders and student-traders for key introductions to Chinese suppliers, shipping agents and manufacturers. Many of these links occur at the annual Guangzhou Trade Fair in which buyers and sellers meet and negotiate. For Nigerian students with good Chinese language skills, this is an especially important contact event. Participants pointed out that Nigerians with Chinese 
language ability, but without trade connections, find their interpretation and translation skills open doors and allow them to prove their value.

Participant narratives reveal pride in the personal areas of migrants' lives over which they, their immediate family members, extended kin and tribe, have control. Industriousness was mentioned often, usually in praise of parents small business acumen - pride in accomplishing the possible, despite larger negative economic or political forces. But there was the expressed feeling that parents who worked hard and attempted to be successful, were being unfairly hampered. This was a source of much anger, frustration and sadness as revealed on the episodic form graphs of participants. Countering this, participants mentioned hopeful future prospects, a means by which they could succeed and assist parents and relatives who did not have the option to migrate. Pride in personal ability, in knowing that they would be able to control their futures unhampered by the Nigerian economic and political system over which they have no control, also instilled a sense of freedom and lightheartedness.

\section{Conclusion}

This report centers on the motivations of Nigerians who sojourn in China, ostensibly for the purpose of education. It is part of a wider study that also considers Nigerian adaptation to the Chinese environment, which will be published at a future date.

A wider representation of the Nigerian population would be desirable. In particular, a future study might include Nigerian students enrolled in other Chinese provinces, but more importantly, it might include a wider variety of Nigerians. This study centers on Nigerians of the Igbo tribal group from south-eastern Nigeria. Their common history is bound to trade, commerce and mercantile associations; thus they predominate in China trade. Future studies should attempt to include members from other tribal groups, for example Yoruba, Hausa and Fulani, in order to more accurately represent Nigerians, as a whole. In addition to this, I was unable to locate Nigerian women willing to be interviewed. This issue may be overcome by a woman researcher.

\section{References}

Adler, M., Lodi-Smith, J., Philippe, F., \& Houle, I. (2016). The incremental validity of narrative identity in predicting well-being: A review of the field and recommendations for the future. Personality and Social Psychology Review, 20(2), 142-175. https://doi.org/10.1177/1088868315585068

Agbiboa, D. E. (2012). Between corruption and development: The political economy of state robbery in Nigeria. Journal of Business Ethics, 108(3), 325-345. https://doi.org/10.1007/s10551-011-1093-5

Ajakaiye, O., \& Kaplinsky, R. (2009). China in Africa: A relationship in transition. The European Journal of Development Research, 21(4), 479-484. https://doi.org/10.1057/ejdr.2009.30

Akanle, O. (2012). Kinship support orientations and class dynamics of Nigerian international migrants. International Review of Modern Sociology, 38(1), 131-157.

Altbach, P. (2007). Peripheries and centers: Research universities in developing countries. College and University Journal, 80(2), 3-8.

Becker, E. (1971). The birth and death of meaning: An interdisciplinary perspective on the problem of man. New York: Simon \& Schuster.

Becker, E. (1973). The denial of death. New York: Simon \& Schuster.

Benish-Weisman, M. (2009). Between trauma and redemption: Story form differences in immigrant narratives of successful and nonsuccessful immigration. Journal of Cross-Cultural Psychology, 40(6), 953-968. https://doi.org/10.1177/0022022109346956

Brante, E. (2012). Stand together or fall alone: Narratives from former teachers. Narrative Works: Issues, Investigations \& Interventions, 2(2), 20-40.

Bredeloup, S. (2014). West African students turned entrepreneurs in Asian trading posts: A new facet of globalization. Urban Anthropology and Studies of Cultural Systems and World Economic Development, 43(1/2/3), 17-56.

Bury, M. (2001). Illness narratives: Fact or fiction? Sociology of Health \& Illness, 23(3), 263-285. https://doi.org/10.1111/1467-9566.00252

Clough, P. (2002). Narratives and fictions in educational research. Buckingham: Open University Press.

Giovannetti, G., \& Sanfilippo, M. (2016). Do Chinese exports crowd-out African goods? An econometric 
analysis by country and sector. In S. Henson \& O. F. Yap (Eds.), The power of the Chinese dragon: Implications for African development and economic growth (pp. 10-41). London: Palgrave Macmillan UK.

Gonzalez-Lopez, G. (2015). Family secrets: Stories of incest and sexual violence in Mexico. New York: NYU Press.

Goodley, D. (2004). Gerry O'Toole: A design for life. In D. Goodley, R. Lawthom, P. Clough, \& M. Moore (Eds.), Researching life stories: Method, theory and analysis in a biographical age (pp. 3-14). London: Routledge Falmer.

Government of China. (2018). Growing number of foreign students choosing to study in China for a degree across multiple disciplines. Beijing: Government of The People's Republic of China. Retrieved from http://en.moe.gov.cn/News/Top_News/201804/t20180403_332258.html

Gray, D. (2001). Accommodation, resistance and transcendence: Three naratives of autism. Social Science \& Medicine, 53, 1247-1257. https://doi.org/10.1016/S0277-9536(00)00424-X

Gregen, K., \& Gregen, M. (1986). Narrative form and the construction of psychological science. In T. Sarbin (Ed.), Narrative psychology: The storied nature of human conduct (pp. 22-24). New York: Praeger.

Gregen, K., \& Gregen, M. (1988). Narrative and the self as relationship. In L. Berkowitz (Ed.), Advances in experimental social psychology. San Diego: Academic Press.

Hammack, P. (2008). Narrative and the cultural psychology of identity. Personality and Social Psychology Review, 12, 222-247. https://doi.org/10.1177/1088868308316892

Haugen, H. (2012). Nigerians in China: A second state of immobility. International Migration Review, 50(2), 65-80. https://doi.org/10.1111/j.1468-2435.2011.00713.x

Hoskins, J. (2007). Who owns a life history? Scholars and family members in dialogue. In R. Waterson (Ed.), Southeast Asian lives: Personal narratives and historical experience. Singapore: National University of Singapore Press.

Human Rights Watch. (2019). Nigeria events of 2017. Retrieved from https://www.hrw.org/world-report/2018/country-chapters/nigeria\#ea6b87

Klots, Y. (2011). The ultimate city: New York in Russian immigrant narratives. The Slavic and East European Journal, 55(1), 38-57.

Ladefoged, P. (1988). Hierarchical features of the International Phonetic Alphabet. Paper presented at the fourteenth annual meeting of the Berkeley Linguistics Society, Berkeley.

Lagree, J. C. (2012). Coping with the internationalization of higher education in China. In L. Perlin \& L. Roulleau-Berger (Eds.), China's internal and international migrations (pp. 174-201). London: Routledge.

Lieblich, A., Tuval-Mashiach, R., \& Zilber, T. (1998). Narrative research: Reading, analysis, and interpretation. Thousand Oaks: Sage.

Linde, C. (1993). Life stories: The creation of coherence. New York: Oxford University Press.

Maiangwa, B., Uzodike, U. O., Whetho, A., \& Onapajo, H. (2012). Baptism by fire: Boko Haram and the reign of terror in Nigeria. Africa Today, 59(2), 41-57. https://doi.org/10.2979/africatoday.59.2.41

Martyn, H. L. (2018a). Narratives as catalysts for transformation and social action planning within the Hong Kong Indonesian migrant community. Asian Social Science, 14(6), 106-117. https://doi.org/org/10.5539/ass.v14n6p106

Martyn, H. L. (2018b). Voices of Indonesian migrant workers at home and abroad. Asian Social Science, 14(8), 119-131. https://doi.org/10.5539/ass.v14n8p119

McAdams, D., Diamond, A., de St. Aubin, E., \& Mansfield, E. (1997). Stories of commitment: The psychosocial construction of generative lives. Journal of Personality and Social Psychology., 72, 678-694.

Ministry of Education. (2016). China releases report on foreign students for 2015. Retrieved from http://en.moe.gov.cn/News/Top_News/201604/t20160420_239196.html

Ministry of Education. (2019). Statistical report on international students in China for 2018. Retrieved from http://en.moe.gov.cn/documents/reports/201904/t20190418_378692.html

Moore, M. (2004). The death story of David Hope. In D. Goodley, R. Lawthom, P. Clough, \& M. Moore (Eds.), Researching life stories: Method, theory and analyses in a biographical age (pp. 26-39). London: 
Routledge Falmer.

Morris, D. (2017). Varieties of erotic experience: Five illness narratives. In D. Morris (Ed.), Eros and illness (pp. 107-134): Harvard University Press.

Murray, H. (2010). Not in this family: Gays and the meaning of kinship in postwar North America. University of Pennsylvania Press.

Obi, C. (2010). African migrants as the search for a wonderful world: An emerging trans-global security threat? African and Asian Studies, 9(1-2). https://doi.org/10.1163/156921010X491290

OECD. (2016). "How many students study abroad?". OECD Factbook 2015-2016: Economic, Environmental and Social Statistics. https://doi.org/10.1787/factbook-2015-71-en

Oṣoba, S. O. (1969). The phenomenon of labor migration in the era of British colonial rule: A neglected aspect of Nigeria's social history. Journal of the Historical Society of Nigeria, 4(4), 515-538.

Pavelko, S., \& Owens, R. (2017). Sampling utterances and grammatical analysis revised (SUGAR): New normative values for language sample analysis measures. Language, Speech and Hearing Services in Schools, 48(3). https://doi.org/10.1044/2017_LSHSS-17-0022

Peters, M., \& Besley, T. (2018). China's double first class strategy. Educational Philosophy and Theory. https://doi.org/10.1080/00131857.2018.1438822

Riessman, C. K. (2015). Ruptures and sutures: Time, audience and identity in an illness narrative. Sociology of Health \& Illness, 37(7), 1055-1071. https://doi.org/10.1111/1467-9566.12281

UNDP. (2018). Human development reports. Retrieved from http://hdr.undp.org/en/countries

Waterson, R. (Ed.) (2007). South East Asian lives: Personal narratives and historical experience. Singapore: National University of Singapore Press.

Wen, W., \& Hu, D. (2018). The emergence of a regional education hub: Rationales of international students' choice of China as the study destination. Journal of Studies in International Education, 1(23). https://doi.org/10.1177/1028315318797154

Westerhof, G. J. "During my life so much has changed that it looks like a new world to me" A narrative perspective on migrating in time. Journal of Aging Studies, 24(1), 12-19. https://doi.org/10.1016/j.jaging.2008.09.001

White, M., \& Epston, D. (1990). Narrative means to theraputic ends. New York: Norton.

\section{Copyrights}

Copyright for this article is retained by the author(s), with first publication rights granted to the journal.

This is an open-access article distributed under the terms and conditions of the Creative Commons Attribution license (http://creativecommons.org/licenses/by/4.0/). 